\title{
Size Fractionation of Cell-Free DNA in Maternal Plasma Improves the Detection of a Paternally Inherited $\beta$-Thalassemia Point Mutation by MALDI-TOF Mass Spectrometry
}

\author{
Ying $\mathrm{Li}^{\mathrm{a}}$ Edoardo Di Naro ${ }^{\mathrm{b}}$ Angeloantonio Vituccic Simon Grill ${ }^{\mathrm{a}}$ \\ Xiao Yan Zhong a Wolfgang Holzgreve ${ }^{a}$ Sinuhe Hahn ${ }^{a}$ \\ aUniversity Women's Hospital, Department of Biomedicine, University Hospital Basel, Basel, Switzerland; \\ ${ }^{b}$ Department of Obstetrics and Gynecology, and ' Division of Hematology II, University of Bari, Bari, Italy
}

\section{Key Words}

Size fractionation - Cell-free fetal DNA • $\beta$-Thalassemia •

MALDI-TOF mass spectrometry

\begin{abstract}
Objectives: The selective enrichment of cell-free fetal DNA in maternal plasma by size fractionation leads to the improved detection of paternally inherited fetal point mutations when using conventional, real-time PCR, or as has more recently been shown by MALDI-TOF mass spectrometry. We have now examined the use of size fractionation in conjunction with mass spectrometry for the detection of a paternally inherited codon 39 mutation of the $\beta$-globin gene. Methods: Maternal plasma was obtained from an early second trimester pregnancy at risk for $\beta$-thalassemia, where the father carried the codon 39 mutation and the mother was a carrier for the IVSI-110 mutation of the $\beta$-globin gene. Cell-free DNA was analyzed by mutation-specific PCR and MALDI-TOF mass spectrometry for the presence of the codon 39 mutation. A comparison was made between total cell-free DNA and that which had been enriched for a size of 100-300 bp. Results: The paternally inherited codon 39 mutant allele was detectable in both cell-free DNA preparations, but the signal was much more pronounced and pre-
\end{abstract}

cise in the size-fractionated sample. Conclusions: Size fractionation of cell-free DNA may lead to the improved noninvasive detection of fetal point mutations for $\beta$-thalassemia by MALDI-TOF mass spectrometry.

Copyright $\odot 2009$ S. Karger AG, Basel

\section{Introduction}

$\beta$-Thalassemia, caused by $\beta$-globin gene mutations, is regarded as the most frequent monogenic disorder in man [1]. Currently, the prenatal diagnosis of this disorder relies on invasive procedures, such as amniocentesis or chorionic villous sampling, which present a small but significant risk for the fetus [2]. In order to avoid this risk, two alternative non-invasive sources of fetal genetic material have been explored, namely fetal cells in maternal blood and cell-free fetal DNA in maternal plasma [2]. Although fetal $\beta$-globin gene mutations have been correctly determined using fetal cells isolated from the maternal circulation $[3,4]$, this approach is not suitable for the purpose of clinical diagnosis due of the scarcity of fetal cells, requiring the use of complex enrichment and the difficulty of single cell PCR procedures. On the other hand, the analysis of cell-free fetal DNA in maternal plasma has

\section{KARGER}

Fax +41613061234 E-Mail karger@karger.ch www.karger.com
(C) 2009 S. Karger AG, Basel

$1015-3837 / 09 / 0252-0246 \$ 26.00 / 0$

Accessible online at:

www.karger.com/fdt
Sinuhe Hahn, $\mathrm{PhD}$

Laboratory for Prenatal Medicine and Gynecological Oncology

University Women's Hospital/Department of Biomedicine

Hebelstrasse 20, CH-4031 Basel (Switzerland)

Tel. +41 61265 9249, Fax +41 61265 9399, E-Mail shahn@uhbs.ch 
rapidly emerged as the method of choice for non-invasive assessment of fetal genetic loci, especially those completely absent from the maternal genome, such as the fetal rhesus D gene [5].

The detection of more subtle fetal genetic differences between mother and child, such as point mutations, is more difficult due to the vast preponderance of maternal cell-free DNA sequences in maternal plasma. For this reason, appropriate strategies had to be developed. In this context, our laboratory pioneered the approach of size fractionation, whereby fetal cell-free DNA fragments are selected for on the basis of a smaller size than maternal cell-free DNA fragments [6]. We were able to detect paternally inherited point mutations of the $\beta$-globin gene using this procedure [7].

An alternative strategy, developed by the laboratory of Dennis Lo in Hong Kong, was the use of MALDI-TOF (matrix-assisted laser desorption ionization time-offlight) mass spectrometry for the detection of similar fetal point mutations [8]. In our exploration of this technology, we have observed that the enrichment of cell-free fetal DNA fragments by size fractionation would permit more precise determination of fetal SNP (single nucleotide polymorphisms) loci by mass spectrometry [9]. We have now set out to determine whether a similar feature would be observed for the analysis of $\beta$-thalassemia mutations, specifically to detect paternal heritance of a codon 39 mutation.

\section{Methods and Materials}

\section{Subject and Sample Processing}

Ethical approval was obtained from both participating institutions' review boards. $12 \mathrm{ml}$ plasma was shipped frozen from Bari, Italy, by express courier. The maternal blood sample was taken at week $12+3$ prior to chorionic villous sampling. The plasma was cleared by high-speed centrifugation at 16,000 $\mathrm{g}$ for 10 min before the analysis. The plasma DNA was isolated and sizefractionated according to the method used in our previous studies [7]. Briefly, $10 \mathrm{ml}$ of maternal plasma was used for cell-free DNA isolation with commercial column technology (Roche High Pure Template DNA Purification, Switzerland) in combination with a vacuum pump. The extracted cell-free DNA was separated by $1 \%$ agarose gel electrophoresis and the gel fraction with an approximate size of 100-300 bp was carefully excised. The cell-free DNA in this agarose gel fragment was extracted and eluted into $50 \mu \mathrm{l}$ of elution buffer using a QIAEX II Gel Extraction Kit (Qigene, Switzerland).

\section{Assay Design and PCR}

Fetal heritance of the paternal codon 39 mutant allele was examined for using MALDI-TOF mass spectrometry combined with SABER (single allele base extension reaction assay) as de- scribed previously [8]. The assay design was kindly provided by Sequenom, Inc. (San Diego, Calif., USA).

In the first step, the target gene was amplified by PCR. The PCR reactions consisted of $10 \mu$ l of eluted size fractionated DNA, $200 \mathrm{nM}$ of each primer, $2.5 \mathrm{~mm}$ of $\mathrm{Mg}^{2+}$, $0.5 \mathrm{U}$ Hotstar Taq polymerase (Qiagen) in a final reaction volume of $25 \mu$ l. The PCR reaction was carried out with an initial incubation at $95^{\circ} \mathrm{C}$ for 15 min to activate the Taq polymerase, followed by 50 cycles of $94^{\circ} \mathrm{C}$ for $20 \mathrm{~s}, 56^{\circ} \mathrm{C}$ for $30 \mathrm{~s}$ and $72^{\circ} \mathrm{C}$ for $1 \mathrm{~min}$. The final incubation was at $72^{\circ} \mathrm{C}$ for $5 \mathrm{~min}$. The primers used for the PCR were:

PCR-F: 5'-ACGTTGGATGATAGGCACTGACTCTCTCTG-3' PCR-R: 5'-ACGTTGGATGGATCCCCAAAGGACTCAAAG-3'

$10 \mu \mathrm{l}$ of the PCR product was digested with shrimp alkaline phosphatase (Sequenom, Inc.) at $37^{\circ} \mathrm{C}$ for $30 \mathrm{~min}$ and followed by heating at $85^{\circ} \mathrm{C}$ for $5 \mathrm{~min}$. The later step is to dephosphorylate any unincorporated nucleotides.

\section{Primer Extension and Desalting}

The terminator mix, which contains a mixture of ddNTP and dNTPs, was added to the shrimp alkaline phosphatase-treated products. The extension reaction was carried out in an Eppendorf Master PCR thermal cycler (Eppendorf, Germany), using an initial heating step of $94^{\circ} \mathrm{C}$ for $2 \mathrm{~min}$, followed by 55 cycles of $95^{\circ} \mathrm{C}$ for $5 \mathrm{~s}, 52^{\circ} \mathrm{C}$ for $5 \mathrm{~s}$, and $72^{\circ} \mathrm{C}$ for $5 \mathrm{~s} .32 \mu \mathrm{l}$ of distilled $\mathrm{H}_{2} \mathrm{O}$ was added to $18 \mu \mathrm{l}$ of extension products, followed by addition of $6 \mathrm{mg}$ of SpectroClean resin (Sequenom, Inc.) to remove any residual salt.

The extension primers were:

\section{E: 5'-AGGACTCAAAGAACCTCT-3'}

\section{MALDI-TOF MS Data Acquisition and Analysis}

Approximately $15 \mathrm{nl}$ of the desalted product solution was dispensed onto a 384-format SpectroChip using a MassArray ${ }^{\circledR}$ nanodispenser (Sequenom, Inc.). The chip was analyzed by MassArray ${ }^{\circledR}$ Analyzer Compact and the data was recorded and analyzed by MassArray ${ }^{\circledR}$ software.

\section{Results}

The determination of absence or presence of a paternally inherited mutant $\beta$-globin allele can be used to screen pregnancies at risk for $\beta$-thalassemia in those conditions where the parents do not carry the same mutation $[7,8]$. In this study, the sample was taken from a pregnant woman carrying an IVSI-110 mutation, whereas her husband carries a codon 39 mutation in the $\beta$-globin gene. We examined the sample in a blinded manner. Our result indicated that the fetus inherited the paternal codon 39 mutant allele. This was confirmed by an independent analysis of fetal material obtained by chorionic villous sampling, performed in a routine diagnostic laboratory at the University of Bari, Italy. This diagnosis was also confirmed after delivery.

The mass spectra showed that in the analysis of total cell-free DNA, the paternal mutant allele $\mathrm{T}$ (present as A, 


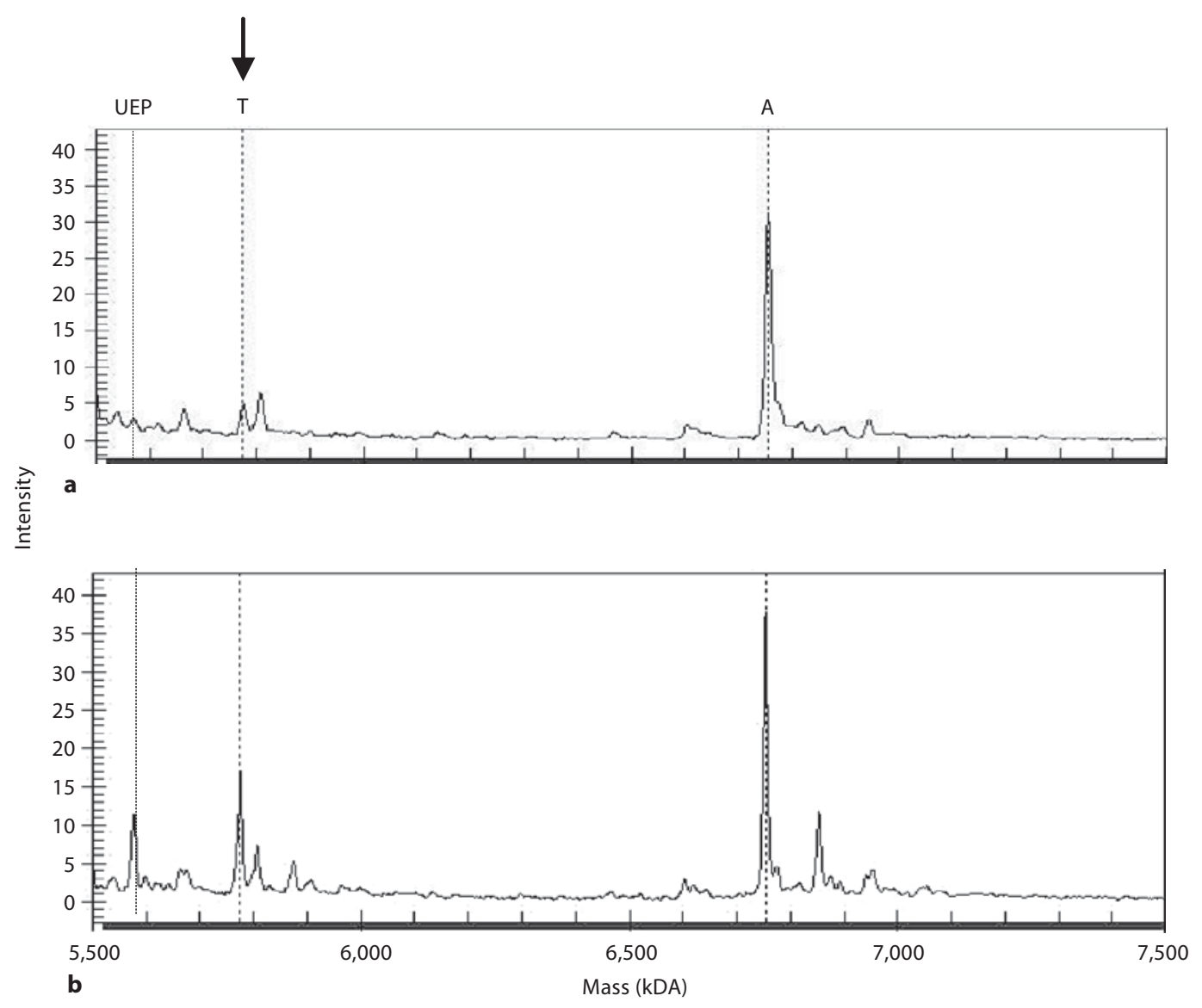

Fig. 1. Detection of paternally inherited codon 39 mutant allele in total and size-fractionated cell-free DNA by MALDI-TOF mass spectrometry. a Minimal detection of the paternal mutant allele (represented by A) in the analysis of total cell-free DNA. b Improved signal detection for the paternal mutant allele (represented by A) in the analysis of size-fractionated cell-free DNA. UEP = Unextended primer, $\mathrm{T}=$ wild-type allele.

due to the reverse extension primer) was discernable over the background trace (fig. 1a). However, the signal for this allele was far more pronounced when the analysis was performed on size-fractionated cell-free DNA (fig. 1b).

\section{Discussion}

Prenatal diagnosis of $\beta$-thalassemia is important in populations with a high prevalence of pertinent mutations [1]. An important clinical contribution will be the possibility to non-invasively determine which pregnancies are at risk of bearing a fetus with $\beta$-thalassemia [2]. This can be achieved in those cases where the parents do not carry the same $\beta$-globin mutation, by determining whether the fetus has inherited the paternal mutant allele or not. Although the potential usefulness of this approach has been investigated in previous studies $[7,8,10,11]$, we have now examined whether the combination of two methods, namely the enrichment of fetal cell-free DNA fragments by size fractionation and MALDI-TOF mass spectrometry, may yield improved results. Compared to PNA-PCR (peptide nucleic acid-PCR) the MALDI-TOF MS approach is much easier to handle and is robust. Many different mutant samples can be performed simultaneously in one set-up. This facet was tested on a case in which the father was a carrier of a codon $39 \beta$-globin mutation, while the mother was a carrier for the IVSI-110 mutation. 
In our analysis we clearly observed that the use of size fractionation led to improved signal detection for the paternally inherited mutant allele, thereby confirming an observation we had previously made regarding the detection of paternally inherited SNP loci [9]. While signal strength is improved, the spectrogram using size-fractionated plasma DNA shows higher background peaks compared to total DNA. Those additional peaks most probably are the result of incomplete desalting of the sample. However, the background signals would not affect the determination since they did not fall into the an- alytical mass ranges. Although promising, our result will need to be verified in a much larger study, which if successful, could pave the way for widespread clinical application in the near future.

\section{Acknowledgements}

This study was funded by grants from the Swiss National Science Foundation (SNF 3200BO-107697/1) and the EU SAFE project (LSHB-CT-2004-503243).

\section{References}

1 Weatherall DJ: Thalassaemia: the long road from bedside to genome. Nat Rev Genet 2004;5:625-631.

$\checkmark 2$ Hahn S, Zhong XY, Holzgreve W: Recent progress in non-invasive prenatal diagnosis. Semin Fetal Neonatal Med 2008;13:57-62.

$\checkmark 3$ Cheung MC, Goldberg JD, Kan YW: Prenatal diagnosis of sickle cell anaemia and thalassaemia by analysis of fetal cells in maternal blood. Nat Genet 1996;14:264-268.

$\checkmark 4$ Di NE, Ghezzi F, Vitucci A, Tannoia N, Campanale D, D'Addario V, et al: Prenatal diagnosis of $\beta$-thalassaemia using fetal erythroblasts enriched from maternal blood by a novel gradient. Mol Hum Reprod 2000;6: 571-574.

5 Lo YM: Recent developments in fetal nucleic acids in maternal plasma: implications to noninvasive prenatal fetal blood group genotyping. Transfus Clin Biol 2006;13:50-52.
-6 Li Y, Zimmermann B, Rusterholz C, Kang A, Holzgreve W, Hahn S: Size separation of circulatory DNA in maternal plasma permits ready detection of fetal DNA polymorphisms. Clin Chem 2004;50:1002-1011.

7 Li Y, Di NE, Vitucci A, Zimmermann B, Holzgreve W, Hahn S: Detection of paternally inherited fetal point mutations for $\beta$-thalassemia using size-fractionated cell-free DNA in maternal plasma. JAMA 2005;293: 843-849.

$>8$ Ding C, Chiu RW, Lau TK, Leung TN, Chan LC, Chan AY, et al: MS analysis of singlenucleotide differences in circulating nucleic acids: application to noninvasive prenatal diagnosis. Proc Natl Acad Sci USA 2004;101: 10762-10767.
9 Li Y, Wenzel F, Holzgreve W, Hahn S: Genotyping fetal paternally inherited SNPs by MALDI-TOF MS using cell-free fetal DNA in maternal plasma: influence of size fractionation. Electrophoresis 2006;27:38893896.

10 Galbiati S, Foglieni B, Travi M, Curcio C, Restagno G, Sbaiz L, et al: Peptide-nucleic acidmediated enriched polymerase chain reaction as a key point for non-invasive prenatal diagnosis of $\beta$-thalassemia. Haematologica 2008;93:610-614.

11 Lazaros L, Hatzi E, Bouba I, Makrydimas G, Dalkalitsis N, Stefos T, et al: Non-invasive first-trimester detection of paternal $\beta$-globin gene mutations and polymorphisms as predictors of thalassemia risk at chorionic villous sampling. Eur J Obstet Gynecol Reprod Biol 2008;140:17-20. 